\title{
Functional stroke symptoms: a prospective observational case series.
}

Short running head: "Functional stroke: a prospective case series."

Department of Psychological Medicine, King's College London.

Authors: Abbeygail Jones, $\mathrm{MSc}^{1}$; Abigail Smakowski, $\mathrm{MSc}^{2}$; Nicola O'Connell, $\mathrm{PhD}^{3}$; Trudie Chalder, $\mathrm{PhD}^{1} ;$ \& Anthony S. David, $\mathrm{MD}^{4 *}$.

${ }^{1}$ Department of Psychological Medicine, King's College London.

${ }^{2}$ Persitent Physical Symptoms Clinical Research and Treatment Unit, South London and Maudsley NHS Foundation Trust.

${ }^{3}$ Department of Public Health and Primary Care, Institute of Population Health, Trinity College

Dublin.

${ }^{4 *}$ Corresponding author. UCL Institute of Mental Health, University College London.

Contact: Tel $02076799286 \quad$ Email: anthony.s.david@ucl.ac.uk

Post: Wing A, 6th floor Maple House, 149 Tottenham Court Road, London W1T 7NF.

Words $=3615$

\section{Abstract}

Objective

Functional symptoms are a common mimic of stroke in acute stroke settings, but there are no clinical guidelines on how to identify or support patients with these symptoms and scant research on their demographic and clinical profile. This paper explores the presentation of patients with functional stroke symptoms at admission to an acute stroke unit and 2-month follow-up.

Methods

We conducted a prospective observational study across four South East London acute stroke units, with a two-month follow-up. Demographic information, clinical data and GP attendances were recorded. Patients completed self-report measures: Cognitive Behavioural Responses Questionnaire short version, Brief Illness Perception Questionnaire, Hospital Anxiety and Depression Scale, Work and Social Adjustment Scale and Short Form Health Survey.

Results

Fifty-six patients (mean age: 50.9 years) were recruited at baseline; 40 with isolated functional symptoms, the remaining functional symptoms in addition to vascular stroke. Thirty-one completed self-report follow-up measures. Of 56 participants, $63 \%$ were female. Patients presented symptoms across modalities, with unilateral and limb weakness the most frequent. There was inconsistent and ambiguous recording of symptoms on medical records. Approximately $40 \%$ of patients reported levels of anxiety and depression above the threshold indicating a probable diagnosis. Higher anxiety was associated with greater resting or all-or-nothing behaviours, embarrassment avoidance and symptom focussing on the CBRQ measure. Only one general health measure on the SF-36, physical functioning, improved at follow-up. Less than half of participants who responded at follow-up were accessing a treatment, though $82 \%$ had ongoing symptoms.

Conclusion

Patients with functional symptoms in stroke settings report substantial distress, associated with cognitive-behavioural responses to symptoms. Follow-up data suggest recovery can be slow, indicating access to supportive interventions should be improved. 
Key words: Case series, Functional neurological symptoms, Observational, Prospective, Stroke. 


\section{Introduction}

A recently described functional syndrome presentation is acute 'functional stroke (mimic)', affecting around $8 \%$ of patients presenting to hyperacute stroke units $\{5\}$. Systematic review $\{6\}$ and metaanalyses report $15 \%$ of patients presenting to stroke settings without vascular stroke have functional symptoms $\{7\}$. Functional symptoms can also occur alongside organic structural illness $\{8\}$. For example, a quarter of individuals with organic motor disorders were shown to have a comorbid functional condition (see also $\{9\}$ ) and this may affect their overall prognosis $\{10\}$.

Functional stroke patients present with a range of symptoms, $\{5\}$ with an acute or gradual onset $\{11$, $12\}$. A retrospective single-site study reported higher rates of weakness, speech and sensory symptoms in patients with functional versus vascular stroke. However, presenting symptoms alone cannot distinguish functional from vascular stroke and associations between symptomatology and clinical outcomes are unknown.

Current evidence suggests functional neurological symptoms are commonly preceded by a significant life or health-related event/injury $\{12-14\}$. A history of cardiovascular disease may also predispose individuals to view stroke-like symptoms as a more significant health event, with consequences for help-seeking and clinician responses.

Illness Cognitions and Psychiatric comorbidity Explanatory models of functional disorders associate symptom onset and maintenance with cognitive biases and behavioural responses $\{15-17\}$. Clinicians describe a reluctance to discuss functional symptoms out of concerns that such conversations may damage patient-clinician relationships $\{18\}$. Unfortunately, this leaves patients without an explanation $\{19-21\}$ and may impact how they view and respond to symptoms. Compared to those with other neurological conditions, patients with functional neurological symptoms report lower levels of personal control $\{22\}$ and are less likely to associate symptoms with life events/stress $\{23\}$.

Individuals with functional symptoms and physical comorbidities show greater 12-month prevalence rates of anxiety, mood and substance use disorders compared to individuals with no health-related symptoms $\{24\}$. However, the presence of a psychiatric comorbidity or psychological stressor is not invariable, as reflected by the new DSM-V criteria $\{25\}$. It may be difficult to determine if psychiatric symptoms precede or follow functional symptoms, but in any event, psychological distress is associated with poorer clinical outcomes $\{26\}$. In interviews, patients commonly report panic symptoms at the onset of functional motor symptoms $\{12,27\}$.

Anxiety may precipitate functional stroke symptoms, as physiological stress-responses induce physical sensations, reinforce threat-perceptions and initiate unhelpful behavioural responses $\{15$, $16,28\}$. In a prospective study of patients with a new diagnosis of stroke/TIA $\{29\} ; 22 \%$ patients met criteria for an anxiety disorder, and this was associated with phobic avoidance, poorer quality of life and lower independence. Different profiles of cognitive and behavioural responses to symptoms have also been associated with anxiety and depression in chronic fatigue syndrome $\{30\}$. We expect similar associations in individuals with functional stroke symptoms, particularly given the added uncertainty surrounding them and limited access to support $\{19-21\}$.

Given the sparsity of literature we set out to recruit a consecutive cohort of patients presenting to acute stroke services with functional stroke symptoms to gain an overview of their presentation and movement through the stroke care pathway; more specifically we set out to study their clinical presentation, current treatment and referral approaches, and cognitive-behavioural responses to 
symptoms. We hoped our findings could be the basis for better identification and management of patients with functional symptoms in stroke services. We predicted that:

1. Patients will show a wide range of stroke-like symptoms and be subject to extensive medical stroke investigations during admission.

2. A high proportion of patients with functional stroke symptoms will have comorbid physical health conditions, cardiovascular risk factors or a recent history of a significant health event.

3. Patients with functional stroke symptoms will score low on their understanding and sense of control over symptoms, sustained at 2-month follow-up.

4. Patients with functional stroke symptoms will report high levels of anxiety.

\section{Methods}

Study setting

Participants were prospectively recruited from 3 hyperacute stroke units (HASUs) and one nonhyperacute unit across four hospital sites in South London and Kent: King's College Hospital, Princess Royal University Hospital, St George's Hospital, and St Thomas' Hospital.

Data collection

Participants were recruited between $4^{\text {th }}$ January 2019 and $31^{\text {st }}$ May 2019. Two researchers attended daily clinical meetings and ward rounds to screen eligible patients. In some cases where researchers were not present at patient admission, stroke clinicians notified researchers of potential participants.

Inclusion Criteria

i. Admitted to a stroke unit with suspected stroke

ii. No stroke aetiology but possible functional presentation; or stroke aetiology with functional symptoms

iii. $\quad$ Aged $\geq 18$ years

iv. Able to communicate in English

\section{Exclusion Criteria}

i. Unable to read English questionnaires

ii. Unable to give fully informed consent

iii. Functional explanation ruled out by symptoms being attributed to another stroke mimic diagnosis

\section{Timeline of data collection}

Baseline

Potential participants were identified following physical examination by stroke clinicians, and often after reviewing of imaging results. If a potential participant was identified, the researcher would approach the medical team to confirm suitability. If deemed eligible, a member of the medical team approached the patient and introduced the researcher to give more details. The researcher described the study, discussed the study information sheet and provided a consent form before completing baseline measures at the bedside. If a potential participant was discharged before being seen, study documents were sent by post and they were consented remotely by phone. With consent, researchers collected clinical notes on patients' admission to the stroke ward and requested the patient's previous five years of GP records. 


\section{2-month follow-up}

Two months after admission, participants who consented were approached to complete the validated self-report questionnaires and report on any ongoing symptoms, treatments or interventions. Follow-up measures were completed by post, phone or online.

\section{Measures}

Cognitive Behavioural Responses Questionnaire - short version (CBRQ)

The $C B R Q$ is an 18-item questionnaire measuring responses to symptoms. Each item is rated from 0 (strongly disagree) to 4 (strongly agree). There are six subscales of three items each measuring different behavioural/cognitive factors: Fear avoidance (e.g. "Physical activity makes my symptoms worse"), Damage beliefs (e.g. "Even though I experience symptoms, I don't think they are actually harming me"), Embarrassment (e.g. "I am embarrassed about my symptoms"), Symptom focusing (e.g. "I think a great deal about my symptoms"), All-or-nothing behaviour (e.g. "I find myself rushing to get things done before I crash") and Resting behaviour (e.g. "I stay in bed to control my symptoms"). Scores are summed across items for each subscale, with higher scores indicating less helpful symptom-related cognitions. The CBRQ has been validated across two chronic fatigue syndrome cohorts and shows good validity, reliability (Cronbach's $\alpha=0.67-0.88$ ) and high factor loadings $\{31\}$.

\section{Hospital Anxiety and Depression Scale (HADS)}

HADS is a 14-item, brief self-report measure consisting of two subscales, developed to identify anxiety and depression in hospital or outpatient settings $\{32\}$ and shows good validity and reliability $\{33\}$. Items are scored from $0-4$. Scores of $\leq 7$ for each subscale are considered in normal range, scores of 8-10 are possible cases and scores of $\geq 11$ are probable cases $\{32\}$.

\section{Brief Illness Perception Questionnaire (IPQ-B)}

IPQ-B consists of 9 items scored from 0-10 \{34\}. Participants are asked to rate the effect of symptoms on their life, symptom duration, control, understanding and experience of symptoms, etc. Scores on the subscales correlate quality of life and future disability $\{35,36\}$.

Work and Social Adjustment Scale (WSAS)

The WSAS is a simple 5-item scale measuring functioning, assessing the impact of symptoms on work, home, social activities and relationships. Each item is scored on a scale from 0 (not at all impaired) to 8 (very severely impaired). It has good validity, reliability and correlates with psychiatric symptom severity $\{37\}$.

\section{6-Item Short Form Survey (SF-36)}

The SF-36 is a questionnaire used to assess general health status across 8 domains: general health perceptions; physical functioning; limitations from physical health; limitations from emotional health; bodily pain; energy/vitality; social functioning; and mental health \{38\}. An algorithm transforms raw scores into scores ranging from 0-100; lower scores indicate poorer health $\{39\}$. Summary scores are calculated for the 8 health dimensions $\{40\}$.

\section{Additional clinical information}

Clinical information gathered for a participant's admission included: symptoms at admission, preadmission risk factors, tests/scans undertaken during admission, comorbid conditions and length of hospital stay. Diagnoses were collected at two time-points: first, initial diagnoses at admission, usually indicated in notes from the emergency department or after the patient's first assessment by the stroke team and second, from the discharge summary sent to GPs. These diagnoses were 
recorded verbatim from medical notes and then grouped. To avoid bias in summarised clinical notes, and ensure an accurate, comprehensive insight to diagnosis, a third 'consensus' diagnosis was allocated by the researchers based on discussion with consultants, the stroke team and after collating all medical notes for the admission.

Ethical considerations

Ethical approval was granted by Health and Research Authority on $10^{\text {th }}$ December 2018 (IRAS reference: 245303) and Riverside Research Ethics Committee (Reference: 18/LO/1878).

Statistical analysis

Relationships between psychological distress and illness perceptions were examined using Spearman's Rho correlation. Independent t-tests were used to compare responses to CBRQ items in those with/without anxiety or depression (i.e. HADS anxiety/depression scores $>8$ ). Baseline and 2month follow-up survey responses from respondents at both time-points were compared using paired sample t-tests or Wilcoxon signed rank tests depending on the distribution of variables. An adjusted $p$-value of .002 for time-point comparisons was used. No cases were excluded for missing data. Where participants had missing items within a measure, scores were prorated on the average of other complete items.

\section{Results}

Sample characteristics

Fifty-six participants (35 females) were recruited (see Table 1 for demographic information). One participant withdrew from the study before completing self-report questionnaires. GP records were available for 42 (75\%) participants, with 16 (28\% GPs records) accessed from electronic patient records. Two-month follow-up measures were completed by 34 participants $(61 \%)$, with three giving only partial follow-up information by not completing self-report questionnaires. Of the 34 participants who completed follow-up measures, 25 were judged to have isolated functional symptoms and 9 had functional symptoms in addition to stroke or other medical conditions. The mean number of days between baseline and follow-up measures was 64 (SD: 20.4 days). Comparing responders at follow-up to non-responders, there were no statistically significant differences in age, duration of symptoms, sex, ethnicity or occupational status (results available from authors on request).

Table 1. Participant demographic and clinical information

\begin{tabular}{lr}
\hline Characteristic & Mean (SD) \\
\hline Age & 50.9 years (13.7) \\
\hline Symptom duration & Median (range) \\
\hline & 7 days (0.5 days- \\
11 years)
\end{tabular}




\begin{tabular}{lr}
\hline Marital status & \\
Married/ Cohabiting & $21(38)$ \\
Single & $18(32)$ \\
Divorced/ Separated & $12(21)$ \\
Widowed & $5(9)$ \\
\hline Occupational status & \\
Employed full-time & $21(38)$ \\
Unemployed/ sick-leave or disabled & $13(23)$ \\
Retired & $9(16)$ \\
Employed part-time/ self employed & $8(14)$ \\
Othert & $5(9)$ \\
\hline
\end{tabular}

† Including Student, Carer.

Clinical information

Admission and discharge information

Thirty-four patients (61\%) arrived at hospital emergency departments by ambulance, Face-ArmSpeech-Test (FAST) screening test positive; one arrived by ambulance but was FAST negative; two were inpatient referrals; eight were transferred from another hospital; eleven were selfpresentations at A\&E. Five (9\%) patients received thrombolysis and none of these had suffered a vascular stroke; as such $13 \%$ patients identified as experiencing only functional symptoms according to their consensus diagnosis received thrombolysis. With respect to medical attention, 50 (89\%) patients had computed tomography-head (CT-head) and 43 (79\%) received a magnetic resonance imaging (MRI) scan. One CT-head demonstrated a definite infarct and one demonstrated a possible infarct. Two MRI scans confirmed an acute infarct and five reported incidental findings. Further investigations included electrocardiogram (ECG) ( $n=31,55 \%), C T$-angiogram ( $n=28,50 \%)$, chest $x$-ray ( $n=15,27 \%)$, doppler ultrasound $(n=8,14 \%)$, echocardiogram $(n=4,7 \%)$ and CT-spine $(n=2,4 \%)$. Length of stay before discharge from the stroke team ranged from two hours to 41 days (median=1.5 days). Fifty-two patients (93\%) were sent directly back into the community. Two patients were transferred to another hospital ward and two were referred to a local hospital.

\section{Presenting symptoms}

Patients reported a range of sensory, motor and language symptoms. Mean number of symptoms at admission was 5.4 ( $\min =1$, $\max =11$ ). Unilateral symptoms affected $89 \%$ patients; three experienced both bilateral and unilateral symptoms during admission. Eight clinical files reported explicit positive 'functional disorder' signs: five recorded positive Hoover's signs, one recorded give-way weakness and one recorded drift with no pronation. Seven further clinical notes included phrases indicative of positive signs for functional symptoms: one recorded "Abnormalities do not fit anatomically", five used terms: inconsistent, variable, fluctuating, intermittent or atypical and one recorded "semivolitional right arm drift". Appendix C shows the frequency of presenting symptoms reported for participants with isolated functional symptoms and those with functional 'overlay'. These two groups could not be meaningfully compared statistically due to small and different sample sizes.

\section{Medical history}

Combining patient self-report comorbid health conditions and notes from hospital records, 18 (32\%) patients had psychiatric conditions currently or in the past, $44(79 \%)$ had cardiovascular risk factors (e.g. high blood pressure, family history of cardiovascular disease, type 2 diabetes) and 15 (27\%) had past history of stroke or transient ischemic attack (TIA). Twelve (21\%) patients had a previous hospital admission for similar symptoms, while eight (14\%) had experienced other unexplained symptoms, including 5 who had a history of non-epileptic (dissociative) seizures or unexplained chest 
pain. Two patients had psychological trauma recorded in medical notes or self-reported. Twentyseven GP records provided consultation statistics. From these records, patients had a mean of $25 \mathrm{GP}$ contacts (range: 1-69 consultations) at surgery or by phone in the last 5 years, i.e. 5/year.

Follow-up symptoms and treatment

At follow-up, 28 (82\%) responders (51\% participants completing baseline measures) were experiencing ongoing symptoms. New symptoms, not reported at baseline, were exhaustion/fatigue $(n=6)$ and memory problems $(n=3)$. Laterality of symptoms remained the same apart from two cases where symptoms became bilateral. The greatest proportion of patients reported being much improved ( $n=13,42 \%)$, followed by no change $(n=7,23 \%)$, very much improved and minimally worse (both $n=5,16 \%$ ) and very much worse $(n=1,3 \%)$. Fourteen participants reported not being offered any treatment or follow-up investigations, 12 of these participants had isolated functional symptoms according to summary diagnoses (Appendix D). Three were referred to a specialist, tailored for functional symptoms treatment (two with isolated functional symptoms and one with functional symptoms in addition to another medical condition) and three were referred to mental health services (two with isolated functional symptoms and one with functional symptoms in addition to a stroke). Eight participants reported being referred for physiotherapy or rehabilitation. 
Table 2. Frequency (F) of presenting symptoms recorded in patient clinical notes.

\begin{tabular}{|c|c|c|c|c|c|c|c|c|c|c|c|c|c|c|c|c|c|}
\hline Laterality & & Pain & & $\begin{array}{l}\text { Systemic / } \\
\text { autonomic }\end{array}$ & & $\begin{array}{l}\text { Speech/ } \\
\text { swallow }\end{array}$ & & Motor & & Onset & & Sensory & & Visual & & Other & \\
\hline Symptom & $F$ & Symptom & $F$ & Symptom & $F$ & Symptom & $F$ & Symptom & $F$ & Symptom & $F$ & Symptom & $F$ & Symptom & $F$ & Symptom & $F$ \\
\hline Unilateral & 50 & $\begin{array}{l}\text { Headache/ } \\
\text { migraine }\end{array}$ & 23 & Dizziness & 9 & $\begin{array}{l}\text { Dysarthria/ } \\
\text { Slurred } \\
\text { speech }\end{array}$ & 17 & $\begin{array}{l}\text { Lower } \\
\text { limb } \\
\text { weakness }\end{array}$ & 45 & $\begin{array}{l}\text { Confusion/ } \\
\text { disorientation }\end{array}$ & 6 & $\begin{array}{l}\text { Upper limb } \\
\text { sensory } \\
\text { change }\end{array}$ & 22 & Visual loss & 15 & $\begin{array}{l}\text { Inconsistent/ } \\
\text { intermittent }\end{array}$ & $\begin{array}{l}1 \\
1\end{array}$ \\
\hline \multirow[t]{6}{*}{ Bilateral } & 6 & $\begin{array}{l}\text { Pain in } \\
\text { limbs or } \\
\text { body }\end{array}$ & 13 & $\begin{array}{l}\mathrm{LOC}^{\dagger} \\
\text { syncope }\end{array}$ & 5 & Aphasia & 10 & $\begin{array}{l}\text { Upper } \\
\text { limb } \\
\text { weakness } \\
\end{array}$ & 41 & $\begin{array}{l}\text { Onset on } \\
\text { waking }\end{array}$ & 5 & $\begin{array}{l}\text { Lower limb } \\
\text { sensory } \\
\text { change } \\
\end{array}$ & 19 & Diplopia & 2 & Photophobia & 1 \\
\hline & & & & $\begin{array}{l}\text { Feeling } \\
\text { slow/tired }\end{array}$ & 5 & Stuttering & 5 & $\begin{array}{l}\text { Facial } \\
\text { droop/ } \\
\text { weakness }\end{array}$ & 13 & $\begin{array}{l}\text { Noticed by } \\
\text { someone else }\end{array}$ & 3 & $\begin{array}{l}\text { Facial } \\
\text { numbness }\end{array}$ & 12 & Nystagmus & 1 & Twitching & 1 \\
\hline & & & & Panic & 4 & $\begin{array}{l}\text { Swallow } \\
\text { symptoms }\end{array}$ & 2 & $\begin{array}{l}\text { Limb } \\
\text { ataxia }\end{array}$ & 8 & Dissociation & 1 & & & Ptosis & 1 & Phonophobia & 1 \\
\hline & & & & Nausea & 3 & & & $\begin{array}{l}\text { Tremor/ } \\
\text { shaking }\end{array}$ & 6 & & & & & & & Vertigo & 1 \\
\hline & & & & Vomiting & 2 & & & $\begin{array}{l}\text { Hand } \\
\text { weakness }\end{array}$ & 3 & & & & & & & $\begin{array}{l}\text { Erratic } \\
\text { behaviour }\end{array}$ & 1 \\
\hline & & & & Seizure & 1 & & & Gait & 4 & & & & & & & $\begin{array}{l}\text { Shortness of } \\
\text { breath }\end{array}$ & 1 \\
\hline
\end{tabular}

${ }^{\dagger}$ LOC $=$ Loss of consciousness 


\section{Diagnoses at admission and discharge}

There were 53 initial diagnoses recorded at admission and 47 diagnoses noted on discharge summaries (Appendix A), collated into the groups seen in Table 3. A list of all diagnoses verbatim from notes alongside their categories can be seen in Appendix A. As expected at admission, initial diagnoses included multiple differentials or "possible/query" diagnoses. In discharge summaries the terms "stress", "anxiety" and "transient" were possibly used as euphemisms for functional symptoms. In three cases, 'negative' diagnoses were stated on discharge summaries (i.e. no organic pathology or non-stroke). Only $64 \%$ patients had 'functional symptoms' recorded on their discharge summary.

Table 3. Diagnoses given in clinical notes at admission and discharge.

\begin{tabular}{|c|c|c|c|c|c|}
\hline \multicolumn{2}{|l|}{ Initial diagnoses at admission } & \multicolumn{2}{|l|}{ Discharge summary diagnoses } & \multicolumn{2}{|l|}{ Consensus diagnoses } \\
\hline Diagnosis listed & $\mathrm{n}$ & Diagnosis listed & $\mathrm{n}$ & Diagnosis listed & $\mathrm{n}$ \\
\hline Stroke & 14 & Functional diagnosis & 24 & Functional symptoms & 40 \\
\hline Functional symptoms & 11 & Stroke & 6 & Stroke with functional sx & 11 \\
\hline Possible stroke & 10 & Migraine with functional sx & 5 & Migraine with functional sx & 5 \\
\hline Stroke or functional & 6 & Migraine & 4 & & \\
\hline TIA & 3 & Functional overlay & 4 & & \\
\hline $\begin{array}{l}\text { Stroke/TIA, migraine or } \\
\text { functional }\end{array}$ & 3 & Stroke with functional sx & 3 & & \\
\hline Migraine or stroke & 3 & Negative diagnosis & 3 & & \\
\hline $\begin{array}{l}\text { Other physical condition } \\
\text { with functional }\end{array}$ & 2 & $\begin{array}{l}\text { Stress exacerbated physical } \\
\text { pathology }\end{array}$ & 2 & & \\
\hline Migraine and functional sx & 2 & No diagnosis stated & 2 & & \\
\hline Leg weakness & 1 & $\begin{array}{l}\text { Anxiety exacerbated physical } \\
\text { pathology }\end{array}$ & 1 & & \\
\hline Seizure & 1 & TIA & 1 & & \\
\hline & & Transient neurological sx & 1 & & \\
\hline
\end{tabular}

sx=symptoms

Self-report measures

Baseline

Totals for questionnaire scales completed at baseline $(n=55)$ and follow-up $(n=31)$ are described in Table 5. Responses to the final BIPQ question on contributory factors were grouped into 15 categories (Table 6). Twenty-three patients stated stress (work, family or social) as the most important cause of symptoms. The second most frequently reported cause was physical illness, injury or cardiovascular risk factors $(n=17)$. Overwork, lack of rest or tiredness, anxiety and worry were also frequently endorsed. Eight patients had no understanding or could not identify any cause for their symptoms. One of the patients endorsing stroke/TIA as a cause had not experienced a vascular stroke.

Associations between distress and cognitive-behavioural responses Total baseline HADS anxiety scores significantly correlated with Embarrassment Avoidance, Symptom Focusing, All or Nothing Behaviour and Resting Behaviour. Baseline HADS depression scores were correlated with Embarrassment Avoidance (Table 4). 
Table 4. Spearman's Rho correlation coefficients between HADS anxiety and depression scores and CBRQ subscale scores.

\begin{tabular}{lllllll}
\hline & $\begin{array}{l}\text { Fear } \\
\text { avoidance }\end{array}$ & $\begin{array}{l}\text { Damage } \\
\text { beliefs }\end{array}$ & Embarrassment & $\begin{array}{l}\text { Symptom } \\
\text { focusing }\end{array}$ & $\begin{array}{l}\text { All or } \\
\text { nothing } \\
\text { behaviour }\end{array}$ & $\begin{array}{l}\text { Resting } \\
\text { behaviour }\end{array}$ \\
\hline $\begin{array}{l}\text { HADS } \\
\text { anxiety }\end{array}$ & .245 & .100 & $.393^{* *}$ & $.393^{* *}$ & $.284^{*}$ & $.309^{*}$ \\
\hline $\begin{array}{l}\text { HADS } \\
\text { depression }\end{array}$ & .245 & -.103 & $.532^{* *}$ & .127 & -.065 & .146 \\
\hline
\end{tabular}

${ }^{*}$ statistically significant to .05 level. ${ }^{* *}$ statistically significant to .01 level

Potential anxiety vs non-anxiety cases

The 21 (38.2\%) patients who were 'probable' cases of anxiety (HADS-A $\geq 11$ ) had higher scores on Embarrassment Avoidance (means: 4.24 vs $7.00, t(53)=-2.41, p=.019$ ) and Symptom Focusing (means: 7.03 vs $8.86, t(53)=-2.28, p=.027$ ).

Potential depression vs non-depression cases

Ten (18.2\%) participants scored $\geq 11$ on HADS-D and scored more highly on Embarrassment avoidance than those who were not depression cases (means: 8.50 vs $4.58, t(53)=-2.76, p=.008$ ).

Follow-up self-report measures

Social and emotional functioning scores on the SF-36 and fear avoidance scores worsened at followup (Table 5), but not to a statistically significant level. A statistically significant improvement between baseline and follow-up was observed for physical functioning $(Z=420.5, p=.001)$ (Figure 1$)$ and damage beliefs ( $\mathrm{t}(30)=2.99, p=.005,95 \% \mathrm{Cls}$ : $0.50,2.66)$, though differences in damage beliefs were not statistically significant. At follow-up, physical illness, injury or cardiovascular risk factors were the most common attribution of symptom cause, followed by stress, overworking and stroke/TIA. 
Table 5. Questionnaire subscale totals at baseline and follow-up.

\begin{tabular}{|c|c|c|c|c|c|}
\hline \multirow[b]{2}{*}{ Questionnaire } & \multirow[b]{2}{*}{ Sub-scale (each score out of 100) } & \multicolumn{2}{|c|}{$\begin{array}{l}\text { Baseline } \\
(n=55)\end{array}$} & \multicolumn{2}{|c|}{$\begin{array}{l}\text { 2-month } \\
\text { follow-up }(n=31)\end{array}$} \\
\hline & & Mean & SD & Mean & SD \\
\hline \multirow{8}{*}{$\begin{array}{l}\text { Short-form Health } \\
\text { Survey }\end{array}$} & Physical functioning & 41.5 & 30.3 & 58.5 & 29.2 \\
\hline & $\begin{array}{l}\text { Role limitations due to physical } \\
\text { health }\end{array}$ & 35.9 & 40.5 & 33.1 & 40.5 \\
\hline & $\begin{array}{l}\text { Role limitations due to emotional } \\
\text { problems }\end{array}$ & 52.2 & 42.9 & 52.7 & 43.7 \\
\hline & Energy/fatigue & 35.2 & 22.6 & 35.6 & 25.1 \\
\hline & Emotional well-being & 61.8 & 25.5 & 54.7 & 31.3 \\
\hline & Social functioning & 56.8 & 32.5 & 46.4 & 34.8 \\
\hline & Pain & 42.5 & 30.3 & 46.2 & 34.7 \\
\hline & General health & 47.5 & 23.3 & 41.2 & 22.7 \\
\hline \multirow{2}{*}{$\begin{array}{c}\text { Hospital Anxiety } \\
\text { and Depression } \\
\text { Scale }\end{array}$} & HADS Anxiety total & 9.2 & 4.9 & 9.7 & 6.6 \\
\hline & HADS Depression total & 6.4 & 4.2 & 6.9 & 5.2 \\
\hline \multirow{6}{*}{$\begin{array}{c}\text { Cognitive } \\
\text { Behavioural } \\
\text { Responses } \\
\text { Questionnaire }\end{array}$} & Fear avoidance total & 4.5 & 2.3 & 5.6 & 2.9 \\
\hline & Damage beliefs total & 8.3 & 2.2 & 6.6 & 2.4 \\
\hline & Embarrassment avoidance total & 5.3 & 4.3 & 4.6 & 4.7 \\
\hline & Symptom focusing total & 7.7 & 3.0 & 7.4 & 3.6 \\
\hline & All or nothing behaviour total & 8.0 & 3.3 & 7.5 & 4.0 \\
\hline & Resting behaviour total & 5.3 & 3.5 & 5.2 & 3.5 \\
\hline \multirow{6}{*}{$\begin{array}{l}\text { Work and Social } \\
\text { Adjustment Scale }\end{array}$} & Work impaired & 5.5 & 2.7 & 4.9 & 3.3 \\
\hline & Home management impaired & 5.0 & 2.7 & 4.4 & 2.8 \\
\hline & Social leisure impaired total & 4.7 & 3.2 & 4.0 & 3.1 \\
\hline & Private leisure impaired total & 4.1 & 3.1 & 3.1 & 2.8 \\
\hline & Relationships impaired total & 2.7 & 2.8 & 2.9 & 3.2 \\
\hline & WSAS total & 23 & 23 & 18.9 & 12.3 \\
\hline \multirow{8}{*}{$\begin{array}{c}\text { Brief Illness } \\
\text { Perception } \\
\text { Questionnaire }\end{array}$} & Consequences & 6.8 & 2.8 & 6.2 & 3.2 \\
\hline & Timeline & 4.9 & 3.3 & 5.2 & 2.7 \\
\hline & Personal control & 6.8 & 2.9 & 6.7 & 3.2 \\
\hline & Treatment control & 2.9 & 2.8 & 4.4 & 3.7 \\
\hline & Identity & 6.6 & 2.7 & 6.5 & 2.6 \\
\hline & Concern & 7.2 & 3.4 & 6.4 & 3.4 \\
\hline & Understanding & 5.2 & 3.6 & 5.4 & 3.6 \\
\hline & Emotional response & 6.8 & 3.1 & 6.5 & 3.3 \\
\hline
\end{tabular}


Table 6. Most important causes of symptoms reported by patients

\begin{tabular}{lrrrr}
\hline & Baseline & & 2-month follow-up \\
\hline Cause of symptom categories & $\begin{array}{r}\text { Frequency } \\
\text { category } \\
\text { endorsed }\end{array}$ & $\begin{array}{r}\text { Number } \\
\text { patients } \\
\text { endorsing cause }\end{array}$ & $\begin{array}{r}\text { Frequency } \\
\text { category } \\
\text { endorsed }\end{array}$ & $\begin{array}{r}\text { Number } \\
\text { patients } \\
\text { endorsing } \\
\text { cause }\end{array}$ \\
\hline Stress & 38 & 33 & 11 & 11 \\
Physical illness, injury or risk factor & 17 & 16 & 13 & 12 \\
Overworking, lack of rest, tiredness & 13 & 11 & 9 & 7 \\
Anxiety or worry & 11 & 8 & 1 & 1 \\
No understanding or response & 8 & 8 & & 2 \\
Sleep & 6 & 6 & 2 & 4 \\
Migraine or headache & 5 & 5 & & 6 \\
General health-related factors & 5 & 5 & 5 & 3 \\
Stroke or TIA & 4 & 4 & 6 & 3 \\
Medical procedures or medication & 3 & 2 & 3 & \\
Bereavement & 3 & 3 & & \\
Psychiatric history & 2 & 2 & 1 & \\
Psychological trauma & 2 & 2 & & \\
Lack research/knowledge & 2 & 3 & & \\
Family history/ hereditary & 1 & 1 & & \\
\hline
\end{tabular}




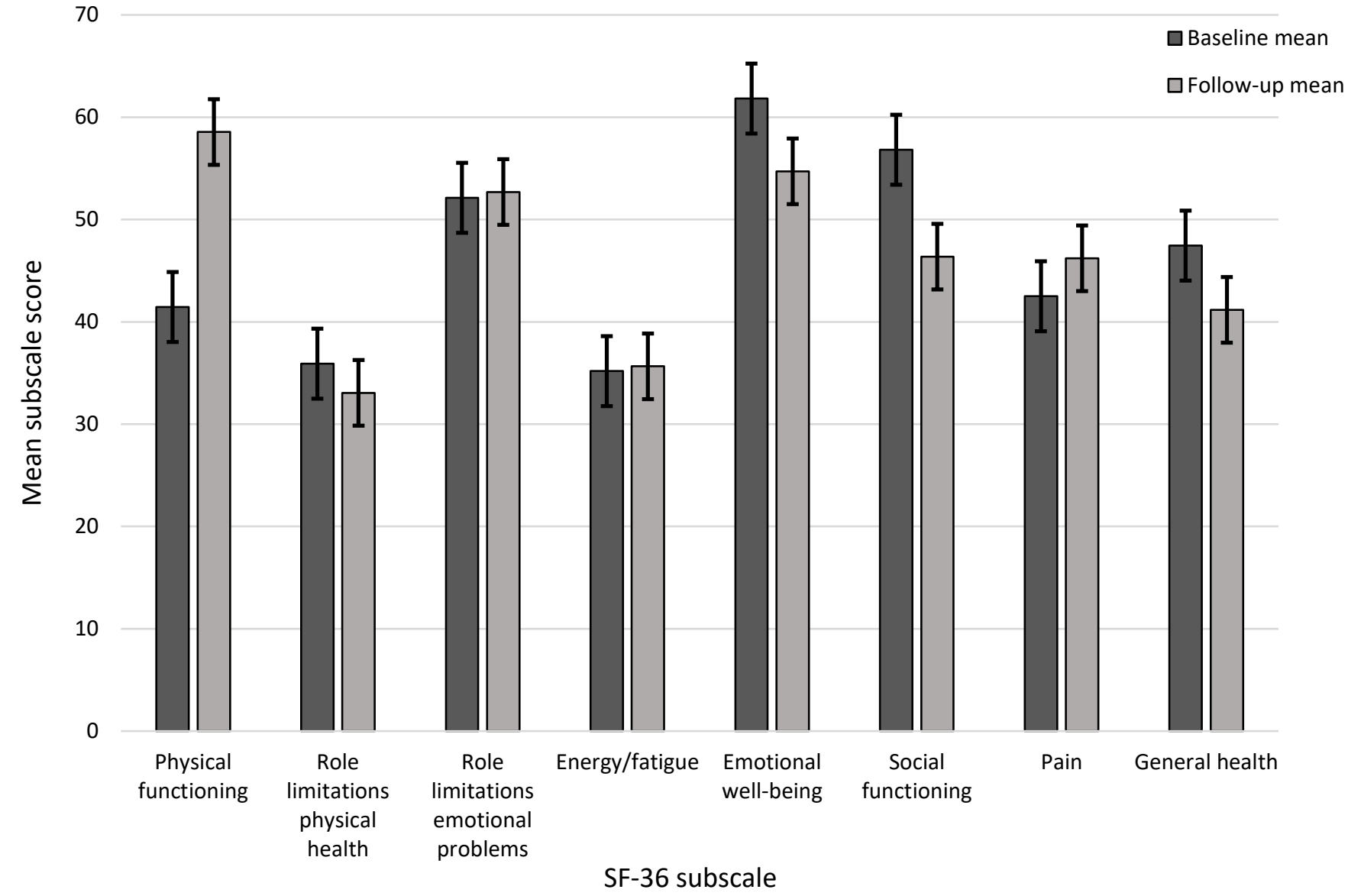

Figure 1. Mean subscale scores of short from health survey at baseline and 2-month follow-up. 


\section{Discussion}

This paper describes the demographic and clinical characteristics of a prospective sample of 56 patients with functional stroke symptoms, with a two-month follow-up. There was a higher proportion of females, consistent with epidemiological research \{2\}. Presenting neurological symptoms were heterogeneous. Amongst patients who agreed to follow-up, $82 \%$ had ongoing symptoms but only $46 \%$ had been offered or were receiving any treatment. In line with our predictions, almost $40 \%$ patients reached the cut-off indicating a probable diagnosis of anxiety and approximately half reached this level for depression. Levels of anxiety were correlated with illness beliefs and adjustment; in particular, all-or-nothing and resting behaviours, embarrassment avoidance, symptom focussing and resting behaviours. Anxiety cases reported greater symptom focussing and embarrassment avoidance than non-cases. Depression scores correlated with embarrassment avoidance, as found previously in patients with chronic fatigue $\{30\}$. Patients with functional stroke symptoms reported only moderate understanding and little sense of control over symptoms. Consistent with our hypotheses, self-report measures were mostly stable at follow-up, with only physical functioning improving significantly.

\section{Clinical profile}

Almost all patients had unilateral symptoms and, most frequently limb weakness. Sixteen (28.6\%) were judged to have functional symptoms in addition to a vascular stroke or migraine. There were inconsistencies between diagnoses at admission, consensus diagnoses gained from discussion/clinical notes and diagnoses at discharge. This suggests real uncertainties in making a firm diagnosis in the acute stroke setting. Nevertheless, there is a need for clear, detailed medical notes; accurate diagnoses are consequential for ongoing care, as discharge summaries are used by GPs and other health care professionals to guide long term treatment. A third of participants had current or past psychiatric diagnoses. Formal psychiatric comorbidity was therefore not a reliable indicator of functional symptoms $\{2,16\}$. Just over three quarters (78.6\%) had cardiovascular risk factors and approximately a fifth reported recent surgery, illness or injury supports. Notably, two thirds of patients did not give a past history of unexplained or functional symptoms, suggesting that for most, this was the first time they had experienced them. These findings are similar to acute functional motor disorder $\{12\}$ and suggest that relevant physical health related factors are pertinent in shaping patients' symptoms as well as medical responses to such symptoms. A history of psychological trauma was only identified in two patients, though it is unlikely this would have been explored in consultations with stroke clinicians.

\section{Investigations}

$89 \%$ received a CT-head scan and $79 \%$ underwent a MRI. High figures for imaging utilisation may reflect changes to UK stroke care targets aiming to increase the proportion of suspected stroke patients receiving brain imaging within 12 hours of an emergency admission $\{41\}$. Previous estimates from the US $\{42\}$ have reported between $92-95 \%$ patients with a final diagnosis of stroke after emergency admission received CT imaging while MRI usage ranged from $55-79 \%$ across states, placing our findings at the higher end of imaging utilisation and indicating patients with functional symptoms contribute a substantial cost to stroke services.

Perceptions and impact of symptoms

Functional stroke symptoms were associated with a high level of self-reported symptoms in general with associated high levels of concern about their severity and consequences. Similar to Binzer (1997) $\{22\}$ patients reported relatively low levels of personal control over symptoms. 
The range of symptom attributions made by participants reflected the three dimensions proposed by Robbins and Kirmayer (1991): psychological, somatic and normalising. As such, patients demonstrated a reasonably flexible approach which should give confidence to clinicians working with such patients $\{23\}$. Symptom attributions remained varied at 2-month follow-up, with physical attributions, overwork and stress being the most frequent again.

The stability of most of the self-report measures (over this relatively short period) likely corresponds to the fact that the majority (82\%) of patients experienced ongoing symptoms, though most said their overall condition had improved. Although physical functioning improved significantly, scores remained rather low compared to general population samples $\{39\}$.

Implications

Our findings go some way in explaining how patients without stroke end up in the stroke pathway. Having not had similar experiences before and with an awareness of cardiovascular risk factors, the patients may be more likely to engage in symptom focussing and perceive symptoms as a sinister health event, leading them to present to emergency services. Once in the stroke system, it is the burden of the stroke clinician to provide evidence against a stroke amidst uncertainties. This may sustain anxiety and promote dysfunctional behavioural responses.

Despite the persistence of symptoms, less than half of patients were offered treatment or support. This highlights the need for a clearer care pathway for this patient group. The average annual GP attendance rate for our sample was already greater than the national average which has been estimated at 3.8 consultations per year $\{44\}$. Offering an intervention for ongoing neurological symptoms could lead to healthcare savings in the long term.

Strengths and limitations

This paper built on previous retrospective research $\{5\}$ by collecting a prospective sample. There was some attrition, which could have biased our results and certainly limited the power of our analyses. Self-report measures may result in an underestimate of psychological distress since patients with functional symptoms may have a lower recognition of anxiety symptoms $\{45\}$. Unfortunately, we were unable to recruit a vascular stroke control group. This $\mathrm{n}$ would have allowed us to comment on the specificity of the characteristics found within our cohort. Future research may seek to recruit a larger sample, with a suitable control group, and address attrition, enabling the use of more powerful statistical analyses to predict outcomes and identify important clinical sub-groups. Positioning researchers in emergency departments may be one way of increasing sample size. Furthermore, exploring differences between patients discharged from emergency departments versus inpatient admissions may give insight to how functional symptoms are identified in stroke settings. Research using a structured clinical interview would add robust diagnoses to our findings on psychological distress. Finally, expert consensus on the diagnosis of migraine and its implications in stroke settings would be valuable.

We acknowledge that while brain imaging is a sensitive tool for identifying vascular stroke, it is possible for some to go undetected. However, the experienced, specialist stroke clinicians providing diagnosis, and the tendency to err on the side of caution suggests that few cases would be missed. Conversely, functional symptoms are often very underreported, especially in conventional stroke services. Symptoms like dissociation are unlikely to be spontaneously reported by patients and physicians in these environments are unlikely to directly ask about them. False negative functional diagnoses probably affected our sample and is a general concern. 


\section{Conclusion}

Patients with functional stroke report broadly similar responses to symptoms as patients with functional motor symptoms in outpatient settings. Patients report high levels of psychological distress, especially anxiety, sustained at 2-month follow-up. Patients receive intense medical investigations, but the recording of functional diagnoses was inconsistent - a finding reflected in patients' own understanding. Despite most followed-up responders experiencing ongoing symptoms, less than half were offered an intervention. There is a need for clearer guidance on communicating functional diagnoses and support with these symptoms in acute stroke settings.

\section{Declaration of interests}

The authors have no competing interests.

\section{Acknowledgements}

We are indebted to all the stroke clinicians, patients and families who contributed to this research.

\section{Funding}

This paper was funded by King's Health Partners R\&D Challenge Fund (RE13522). ASD is supported by the UCLH National Institute of Health Research Biomedical Research Centre. TC is supported by the Department of Health via the National Institute for Health Research (NIHR) Specialist Biomedical Research Centre for Mental Health award to the South London and Maudsley NHS Foundation Trust (SLaM) and the Institute of Psychiatry at King's College London. 


\section{References}

\{1\} American Psychiatric Association: Diagnostic and statistical manual of mental disorders. Washington DC, American Psychiatric Association, 2013

\{2\} Espay AJ, Aybek, S., Carson, A., Edwards, M.J., Goldstein, L.H., Hallett, M., LaFaver, K., Curt LaFrance, W., Lang, A.E., Nicholson, T., Nielsen, G., Reuber, M., Voon, V., Stone, J., Morgante, F. : Functional Neurological Disorders: Current Concepts in Diagnosis and Treatment. JAMA Neurology 2018;

\{3\} Snijders TJ, de Leeuw FE, Klumpers UM, Kappelle $L$ and van Gijn J: Prevalence and predictors of unexplained neurological symptoms in an academic neurology outpatient clinic--an observational study. Journal of Neurology 2004; 251:66-71

\{4\} Nimmuan C, Hotopf M and Wessely S: Medically unexplained symptoms. An epidemiological study in seven specialties. Journal of Psychosomatic Research 2001; 51:361-367

\{5\} Gargalas S, Weeks R, Khan-Bourne N, Shotbolt P, Simblett S, Ashraf L, . . David A: Incidence and outcome of functional stroke mimics admitted to a hyperacute stroke unit. Journal of Neurology Neurosurgery and Psychiatry 2015; 88:2-6

$\{6\}$ Gibson LM and Whiteley W: The differential diagnosis of suspected stroke: a systematic review. Royal College of Physicians in Edinburgh 2013; 43:114-118

\{7\} Jones A, O'Connell $\mathrm{N}$ and David AS: The epidemiology of functional stroke mimic (FSM) patients: a systematic review and meta-analysis. European Journal of Neurology 2019;

\{8\} Reuber M, Mitchell, A.J., Howlett, S.J., Crimlisk, H.L., \& Grunewald, R.A.: Functional symptoms in neurology: questions and answers. Journal of Neurology, Neurosurgery \& Psychiatry 2005; 76:307-

314

\{9\} Wilshire CE and Ward T: Psychogenic Explanations of Physical Illness: Time to Examine the Evidence. Perspectives on psychological science : a journal of the Association for Psychological Science 2016; 11:606-631

$\{10\}$ van Eck van der Sluijs JF, ten Have M, de Graaf R, Rijnders CAT, van Marwijk HWJ and van der Feltz-Cornelis CM: Predictors of Persistent Medically Unexplained Physical Symptoms: Findings From a General Population Study. 2018; 9:

\{11\} Chernyshev OY, Martin-Schild S, Albright KC, Barreto A, Misra V, Acosta I, . . Savitz SI: Safety of tPA in stroke mimics and neuroimaging-negative cerebral ischemia. Neurology 2010; 74:1340-1345

$\{12\}$ Stone J, Warlow $C$ and Sharpe M: Functional weakness: clues to mechanism from the nature of onset. Journal of Neurology, Neurosurgery \& Psychiatry 2012; 83:67-69

$\{13\}$ Nicholson TR, Aybek S, Craig T, Harris T, Wojcik W, David AS and Kanaan RA: Life events and escape in conversion disorder. Psychological Medicine 2016; 46:2617-2626

$\{14\}$ Klem F, Wadhwa, A., Prokop, L.J., Sundt, W.J., Farrugia, G., Camilleri, M., Singh, S., Grover, M.: Prevalence, Risk Factors, and Outcomes of Irritable Bowel Syndrome After Infectious Enteritis: A Systematic Review and Meta-analysis - Gastroenterology. Gastroenterology 2019; 152:1042-1054 $\{15\}$ Deary V, Chalder T and Sharpe M: The cognitive behavioural model of medically unexplained symptoms: a theoretical and empirical review. Clinical Psychology Review 2007; 27:781-797

$\{16\}$ Fobian $A D$ and Elliott $L: A$ review of functional neurological symptom disorder etiology and the integrated etiological summary model. Journal of psychiatry \& neuroscience : JPN 2018; 43:170-190 \{17\} Spence MJ and Moss-Morris R: The cognitive behavioural model of irritable bowel syndrome: a prospective investigation of patients with gastroenteritis. Gut 2007; 56:1066-1071

\{18\} Monzoni CM, Duncan R, Grünewald R and Reuber M: Are there interactional reasons why doctors may find it hard to tell patients that their physical symptoms may have emotional causes? $A$ conversation analytic study in neurology outpatients. Patient Education and Counseling 2011; 85:e189-e200

\{19\} Gelauff J, Stone J, Edwards M and Carson A: The prognosis of functional (psychogenic) motor symptoms: a systematic review. Journal of Neurology, Neurosurgery \& Psychiatry 2014; 85:220-226 $\{20\}$ Nettleton S, O'Malley L, Watt I and Duffey P: Enigmatic Illness: Narratives of Patients who Live with Medically Unexplained Symptoms. Social Theory \& Health 2004; 2:47-66 
\{21\} Robson C and Lian OS: "Blaming, shaming, humiliation": Stigmatising medical interactions among people with non-epileptic seizures. Wellcome Open Research 2017; 2:

\{22\} Binzer M, Andersen, P. M., Kullgren, G.: Clinical characteristics of patients with motor disability due to conversion disorder: a prospective control group study. Journal of neurology, neurosurgery, and psychiatry 1997; 63:83-88

\{23\} Stone J, Warlow C and Sharpe M: The symptom of functional weakness: a controlled study of 107 patients. Brain : a journal of neurology 2010; 133:1537-1551

$\{24\}$ van Eck van der Sluijs J, ten Have, M., Rijnders, C., van Marwijk, H., de Graaf, R., van der FeltzCornelis, C.: Medically Unexplained and Explained Physical Symptoms in the General Population: Association with Prevalent and Incident Mental Disorders. PLOS ONE 2019; 10:e0123274

$\{25\}$ van der Hoeven RM, Broersma M, Pijnenborg GH, Koops EA, van Laar T, Stone J and van Beilen $M$ : Functional (psychogenic) movement disorders associated with normal scores in psychological questionnaires: A case control study. Journal of Psychosomatic Research 2015; 79:190-194

$\{26\}$ Carson AJ, Ringbauer B, Mackenzie L, Warlow C and Sharpe M: Neurological disease, emotional disorder, and disability: they are related: a study of 300 consecutive new referrals to a neurology outpatient department. Journal of neurology, neurosurgery, and psychiatry 2000; 68:202-206 \{27\} Pareés I, Saifee TA, Kassavetis P, Kojovic M, Rubio-Agusti I, Rothwell JC, . . Edwards MJ: Believing is perceiving: mismatch between self-report and actigraphy in psychogenic tremor. Brain : a journal of neurology 2012; 135:117-123

\{28\} Lehn A, Gelauff J, Hoeritzauer I, Ludwig L, McWhirter L, Williams S, . . Stone J: Functional neurological disorders: mechanisms and treatment | SpringerLink. Journal of Neurology 2016; 263:611-620

\{29\} Chun HY, Whiteley WN, Dennis MS, Mead GE and Carson AJ: Anxiety After Stroke: The Importance of Subtyping. Stroke 2018; 49:556-564

\{30\} Cella M, White, P.D., Sharpe, M., Chalder, T.: Cognitions, behaviours and co-morbid psychiatric diagnoses in patients with chronic fatigue syndrome | Psychological Medicine | Cambridge Core. Psychological Medicine 2019; 43:375-380

\{31\} Ryan EG, Vitoratou S, Goldsmith KA and Chalder T: Psychometric Properties and Factor Structure of a Long and Shortened Version of the Cognitive and Behavioural Responses Questionnaire. Psychosomatic Medicine 2018; 80:230-237

\{32\} Zigmond AS and Snaith RP: The hospital anxiety and depression scale. Acta Psychiatrica Scandinavica 1983; 67:361-370

\{33\} Bjelland I, Dahl AA, Haug TT and Neckelmann D: The validity of the Hospital Anxiety and Depression Scale. An updated literature review. Journal of Psychosomatic Research 2002; 52:69-77 \{34\} Broadbent E, Petrie KJ, Main J and Weinman J: The Brief Illness Perception Questionnaire. Journal of Psychosomatic Research 2006; 60:631-637

\{35\} Basu S and Poole J: The Brief Illness Perception Questionnaire. Occupational Medicine 2016; 66:419-420

\{36\} Broadbent E, Wilkes C, Koschwanez H, Weinman J, Norton S and Petrie KJ: A systematic review and meta-analysis of the Brief Illness Perception Questionnaire. Psychology \& Health 2015; 30:13611385

\{37\} Mundt JC, Marks IM, Shear MK and Greist JH: The Work and Social Adjustment Scale: a simple measure of impairment in functioning. British Journal of Psychiatry 2002; 180:461-464

\{38\} Conceptualization and Measurement of Health for Adults in the Health Insurance Study. RAND Corporation. Santa Monica, CA. https://www.rand.org/pubs/reports/R1987z1.html

\{39\} Burholt V, Nash, P.: Short Form 36 (SF-36) Health Survey Questionnaire: normative data for Wales. Journal of Public Health 2011; 33:587-603

\{40\}: Lins L and Carvalho FM: SF-36 total score as a single measure of health-related quality of life: Scoping review. SF-36 total score as a single measure of health-related quality of life: Scoping review; 4 : 
$\{41\}$ Intercollegiate Stroke Working Party. Sentinal Stroke National Audit programme SSNAP July to September 2013.

\{42\} Burke JF, Kerber KA, Iwashyna TJ and Morgenstern LB: Wide Variation and Rising Utilization of Stroke MRI: Data from Eleven States. Annals of Neurology 2012; 71:179-185

$\{43\}$ Robbins JM and Kirmayer L: Attributions of common bodily symptoms. Psychological Medicine 1991; 21:1029-1045

\{44\} Hobbs RFD, Bankhead C, Mukhtar T, Stevens S, Perera-Salazar R, Holt T and Salisbury C: Clinical workload in UK primary care: a retrospective analysis of 100 million consultations in England, 200714. Lancet (London, England) 2016; 387:2323-2330

\{45\} Dimaro LV, Dawson DL, Roberts NA, Brown I, Moghaddam NG and Reuber M: Anxiety and avoidance in psychogenic nonepileptic seizures: the role of implicit and explicit anxiety. Epilepsy and Behaviour 2014; 33:77-86 
Appendix A. Table of consensus, initial admission and discharge summary diagnoses groups with original diagnoses verbatim from clinical notes.

\begin{tabular}{|c|c|c|c|c|}
\hline $\begin{array}{l}\text { Consensus } \\
\text { diagnosis }\end{array}$ & $\begin{array}{l}\text { Admission } \\
\text { diagnosis } \\
\text { group }\end{array}$ & $\begin{array}{l}\text { Verbatim Initial } \\
\text { diagnosis }\end{array}$ & $\begin{array}{l}\text { Discharge } \\
\text { diagnosis group }\end{array}$ & $\begin{array}{l}\text { Verbatim discharge } \\
\text { summary diagnoses }\end{array}$ \\
\hline Functional & Possible stroke & $\begin{array}{l}\text { Possible small } \\
\text { somatosensory stroke }\end{array}$ & No dx stated & None given \\
\hline Functional & Possible stroke & $\begin{array}{l}\text { Possible ischemic } \\
\text { stroke }\end{array}$ & No dx stated & No diagnosis \\
\hline Functional & Stroke & Clinical R MCA infarct & Negative $\mathrm{dx}$ & No acute infarction \\
\hline Functional & Stroke & R MCA & Negative $\mathrm{dx}$ & $\begin{array}{l}\text { Non-stroke possibility } \\
\text { functional }\end{array}$ \\
\hline Functional & $\begin{array}{l}\text { Stroke/TIA, } \\
\text { migraine or } \\
\text { functional }\end{array}$ & $\begin{array}{l}\text { ?New vascular event } \\
\text { ?non-organic element - } \\
\text { /+ migraine }\end{array}$ & Negative $\mathrm{dx}$ & $\begin{array}{l}\text { Headache and } \\
\text { paraesthesia L leg -> No } \\
\text { organic cause found }\end{array}$ \\
\hline Functional & Possible stroke & ?Pontine infarct & $\begin{array}{l}\text { Functional } \mathrm{dx} \text { or } \\
\text { label }\end{array}$ & $\begin{array}{l}\text { Functional Motor } \\
\text { Disorder }\end{array}$ \\
\hline Functional & Possible stroke & Differential dx stroke & $\begin{array}{l}\text { Functional } d x \text { or } \\
\text { label }\end{array}$ & $\begin{array}{l}\text { Functional Neurological } \\
\text { symptom disorder with } \\
\text { mixed symptoms }\end{array}$ \\
\hline Functional & Possible stroke & $\begin{array}{l}\text { Subacute left MCA } \\
\text { infarct, differential dx } \\
\text { peripheral neuropathy }\end{array}$ & $\begin{array}{l}\text { Functional } \mathrm{dx} \text { or } \\
\text { label }\end{array}$ & $\begin{array}{l}\text { Functional with possible } \\
\text { brachial plexus injury }\end{array}$ \\
\hline Overlay & Possible stroke & ? RPOCS, L MCA infarct & $\begin{array}{l}\text { Functional } \mathrm{dx} \text { or } \\
\text { label }\end{array}$ & $\begin{array}{l}\text { FNS w/dizziness and } \\
\text { speech disturbance }\end{array}$ \\
\hline Functional & TIA & $\begin{array}{l}\text { A \& E: TIA (suspected } \\
\text { diagnosis) }\end{array}$ & $\begin{array}{l}\text { Functional } \mathrm{dx} \text { or } \\
\text { label }\end{array}$ & $\begin{array}{l}\text { From A\&E: TIA, From } \\
\text { clinic: functional }\end{array}$ \\
\hline Functional & $\begin{array}{l}\text { Functional } \\
\text { symptoms }\end{array}$ & $\begin{array}{l}\text { Functional neurological } \\
\text { symptoms }\end{array}$ & $\begin{array}{l}\text { Functional } \mathrm{dx} \text { or } \\
\text { label }\end{array}$ & $\begin{array}{l}\text { Functional Neurological } \\
\text { disorder }\end{array}$ \\
\hline Functional & $\begin{array}{l}\text { Functional } \\
\text { symptoms }\end{array}$ & $\begin{array}{l}\text { Functional neurological } \\
\text { symptoms }\end{array}$ & $\begin{array}{l}\text { Functional } \mathrm{dx} \text { or } \\
\text { label }\end{array}$ & $\begin{array}{l}\text { Functional Neurological } \\
\text { Symptoms }\end{array}$ \\
\hline Functional & $\begin{array}{l}\text { Stroke or } \\
\text { functional }\end{array}$ & ?Stroke vs ?Mimic & $\begin{array}{l}\text { Functional } d x \text { or } \\
\text { label }\end{array}$ & $\begin{array}{l}\text { Panic attack and } \\
\text { Functional neurological } \\
\text { disorder }\end{array}$ \\
\hline Functional & Leg weakness & Leg weakness & $\begin{array}{l}\text { Functional } \mathrm{dx} \text { or } \\
\text { label }\end{array}$ & $\begin{array}{l}\text { Functional Neurological } \\
\text { Syndrome }\end{array}$ \\
\hline Functional & Stroke & $\begin{array}{l}\text { Acute right MCA } \\
\text { syndrome }\end{array}$ & $\begin{array}{l}\text { Functional } \mathrm{dx} \text { or } \\
\text { label }\end{array}$ & Functional disorder \\
\hline Functional & $\begin{array}{l}\text { Functional } \\
\text { symptoms }\end{array}$ & FND & $\begin{array}{l}\text { Functional } \mathrm{dx} \text { or } \\
\text { label }\end{array}$ & FND \\
\hline Functional & Stroke & L ACA infarct & $\begin{array}{l}\text { Functional } \mathrm{dx} \text { or } \\
\text { label }\end{array}$ & FND \\
\hline Functional & Seizure & Seizures & $\begin{array}{l}\text { Functional } \mathrm{dx} \text { or } \\
\text { label }\end{array}$ & $\begin{array}{l}\text { FND, Functional } \\
\text { weakness, non-epileptic } \\
\text { seizures }\end{array}$ \\
\hline Functional & $\begin{array}{l}\text { Functional } \\
\text { symptoms }\end{array}$ & $\begin{array}{l}\text { Functional limb } \\
\text { weakness }\end{array}$ & $\begin{array}{l}\text { Functional } \mathrm{dx} \text { or } \\
\text { label }\end{array}$ & $\begin{array}{l}\text { Functional limb } \\
\text { weakness }\end{array}$ \\
\hline Functional & $\begin{array}{l}\text { Functional } \\
\text { symptoms }\end{array}$ & Not organic symptoms & $\begin{array}{l}\text { Functional } \mathrm{dx} \text { or } \\
\text { label }\end{array}$ & Functional stroke \\
\hline Functional & Stroke & Right lacunar stroke & $\begin{array}{l}\text { Functional } \mathrm{dx} \text { or } \\
\text { label }\end{array}$ & Functional presentation \\
\hline Functional & $\begin{array}{l}\text { Other physical } \\
\text { condition with } \\
\text { functional }\end{array}$ & $\begin{array}{l}\text { Vasovagal episode with } \\
\text { likely functional } \\
\text { overlay }\end{array}$ & $\begin{array}{l}\text { Functional } \mathrm{dx} \text { or } \\
\text { label }\end{array}$ & FND \\
\hline
\end{tabular}




\begin{tabular}{|c|c|c|c|c|}
\hline Functional & Stroke & Clinical R MCA infarct & $\begin{array}{l}\text { Functional } d x \text { or } \\
\text { label }\end{array}$ & $\begin{array}{l}\text { Functional Neurological } \\
\text { disorder }\end{array}$ \\
\hline Functional & $\begin{array}{l}\text { Migraine and } \\
\text { functional sx }\end{array}$ & $\begin{array}{l}\text { Migraine w/functional } \\
\text { overlay or hemiplegic } \\
\text { migraine }\end{array}$ & $\begin{array}{l}\text { Functional } \mathrm{dx} \text { or } \\
\text { label }\end{array}$ & $\begin{array}{l}\text { Functional Neurological } \\
\text { disorder }\end{array}$ \\
\hline Functional & $\begin{array}{l}\text { Functional } \\
\text { symptoms }\end{array}$ & $\begin{array}{l}\text { Anxiety related } \\
\text { transient symptoms } \\
\text { and peripheral } \\
\text { neuropathy }\end{array}$ & $\begin{array}{l}\text { Functional } \mathrm{dx} \text { or } \\
\text { label }\end{array}$ & $\begin{array}{l}\text { Functional } \\
\text { Disorder/Neurological } \\
\text { symptoms-peripheral } \\
\text { neuropathy }\end{array}$ \\
\hline Functional & $\begin{array}{l}\text { Functional } \\
\text { symptoms }\end{array}$ & FNS & $\begin{array}{l}\text { Functional } \mathrm{dx} \text { or } \\
\text { label }\end{array}$ & Functional disorder \\
\hline Functional & $\begin{array}{l}\text { Functional } \\
\text { symptoms }\end{array}$ & Functional syndrome & $\begin{array}{l}\text { Functional } \mathrm{dx} \text { or } \\
\text { label }\end{array}$ & $\begin{array}{l}\text { Functional Neurological } \\
\text { disorder }\end{array}$ \\
\hline Functional & $\begin{array}{l}\text { Stroke or } \\
\text { functional }\end{array}$ & $\begin{array}{l}\text { ?subacute stroke, } \\
\text { ?functional element }\end{array}$ & $\begin{array}{l}\text { Functional } \mathrm{dx} \text { or } \\
\text { label }\end{array}$ & Functional weakness \\
\hline Functional & $\begin{array}{l}\text { Migraine or } \\
\text { stroke }\end{array}$ & ?Stroke vs migraine & $\begin{array}{l}\text { Functional } \mathrm{dx} \text { or } \\
\text { label }\end{array}$ & ?FND \\
\hline Overlay & $\begin{array}{l}\text { Stroke or } \\
\text { functional }\end{array}$ & $\begin{array}{l}\text { Functional neurological } \\
\text { weakness vs stroke } \\
\text { w/overlay }\end{array}$ & Stroke & $\begin{array}{l}\text { Acute infarct left corona } \\
\text { radiata }\end{array}$ \\
\hline Overlay & Stroke & $\begin{array}{l}\text { Haemorrhagic } \\
\text { transformation or } \\
\text { extension of infarct }\end{array}$ & Stroke & $\begin{array}{l}\text { Local extension of left } \\
\text { sided ischemia stroke }\end{array}$ \\
\hline Overlay & Possible stroke & $\begin{array}{l}\text { Possible new ischemic } \\
\text { event }\end{array}$ & Stroke & $\begin{array}{l}\text { Clinical small brainstem } \\
\text { stroke }\end{array}$ \\
\hline Overlay & Stroke & L MCA infarct & Stroke & Stroke \\
\hline Functional & Possible stroke & $\begin{array}{l}\text { Subacute right MCA \& } \\
\text { PCA stroke or } \\
\text { congestive heart } \\
\text { failure }\end{array}$ & Stroke & $\begin{array}{l}\text { Stroke suspected stroke } \\
\text { unspecified }\end{array}$ \\
\hline Overlay & Stroke & Right deep ICH & Stroke & $\begin{array}{l}\text { Right midbrain } \\
\text { haemorrhage }\end{array}$ \\
\hline Overlay & $\begin{array}{l}\text { Functional } \\
\text { symptoms }\end{array}$ & $\begin{array}{l}\text { Variable neurological } \\
\text { symptoms/functional } \\
\text { overlay }\end{array}$ & $\begin{array}{l}\text { Functional } \\
\text { overlay }\end{array}$ & Functional Overlay \\
\hline Functional & Possible stroke & ?Stroke & $\begin{array}{l}\text { Functional } \\
\text { overlay }\end{array}$ & Functional overlay \\
\hline Functional & $\begin{array}{l}\text { Other physical } \\
\text { condition with } \\
\text { functional }\end{array}$ & $\begin{array}{l}\text { ?Functional overlay or } \\
\text { drug induced side } \\
\text { effects }\end{array}$ & $\begin{array}{l}\text { Functional } \\
\text { overlay }\end{array}$ & $\begin{array}{l}\text { Epilepsy drug side effect, } \\
\text { seizures, ?functional } \\
\text { overlay }\end{array}$ \\
\hline Overlay & $\begin{array}{l}\text { Stroke/TIA, } \\
\text { migraine or } \\
\text { functional }\end{array}$ & $\begin{array}{l}\text { Migrainous with } \\
\text { possible small event or } \\
\text { possible functional } \\
\text { overlay }\end{array}$ & $\begin{array}{l}\text { Migraine with } \\
\text { functional sx }\end{array}$ & $\begin{array}{l}\text { Migraine with functional } \\
\text { overlay }\end{array}$ \\
\hline Overlay & Stroke & $\begin{array}{l}\text { Stroke (suspected } \\
\text { stroke) }\end{array}$ & $\begin{array}{l}\text { Migraine with } \\
\text { functional sx }\end{array}$ & $\begin{array}{l}\text { Migraine and Functional } \\
\text { components }\end{array}$ \\
\hline Overlay & $\begin{array}{l}\text { Stroke/TIA, } \\
\text { migraine or } \\
\text { functional }\end{array}$ & $\begin{array}{l}\text { Migraine/ functional } \\
\text { neurological } \\
\text { symptoms/ } \\
\text { demyelinating disease/ } \\
\text { TIA }\end{array}$ & $\begin{array}{l}\text { Migraine with } \\
\text { functional sx }\end{array}$ & $\begin{array}{l}\text { Migraine with functional } \\
\text { overlay }\end{array}$ \\
\hline Functional & $\begin{array}{l}\text { Migraine and } \\
\text { functional sx }\end{array}$ & $\begin{array}{l}\text { Complex migraine } \\
\text { ?Functional }\end{array}$ & $\begin{array}{l}\text { Migraine with } \\
\text { functional sx }\end{array}$ & Migraine ?Functional \\
\hline Functional & $\begin{array}{l}\text { Stroke or } \\
\text { functional }\end{array}$ & Acute stroke vs FNS & $\begin{array}{l}\text { Migraine with } \\
\text { functional sx }\end{array}$ & $\begin{array}{l}\text { FNS in context of } \\
\text { migraine symptoms }\end{array}$ \\
\hline Overlay & TIA & ?High risk TIA & Migraine & Migraine \\
\hline
\end{tabular}




\begin{tabular}{|c|c|c|c|c|}
\hline Overlay & $\begin{array}{l}\text { Migraine or } \\
\text { stroke }\end{array}$ & Migraine and stroke & Migraine & Migraine \\
\hline Functional & $\begin{array}{l}\text { Functional } \\
\text { symptoms }\end{array}$ & $\begin{array}{l}\text { Functional neurological } \\
\text { disorder }\end{array}$ & Migraine & Migraine \\
\hline Functional & $\begin{array}{l}\text { Stroke or } \\
\text { functional }\end{array}$ & $\begin{array}{l}\text { ?lacunar stroke vs } \\
\text { functional }\end{array}$ & Migraine & Migraine \\
\hline Overlay & Stroke & $\begin{array}{l}\text { Posterior circulation } \\
\text { stroke }\end{array}$ & $\begin{array}{l}\text { Stroke with } \\
\text { functional sx }\end{array}$ & $\begin{array}{l}\text { Posterior circulation } \\
\text { stroke with some } \\
\text { functional overlay }\end{array}$ \\
\hline Overlay & $\begin{array}{l}\text { Migraine or } \\
\text { stroke }\end{array}$ & $\begin{array}{l}\text { Migrainous or } \\
\text { cerebella infarct }\end{array}$ & $\begin{array}{l}\text { Stroke with } \\
\text { functional sx }\end{array}$ & $\begin{array}{l}\text { Stroke w/functional } \\
\text { overlay }\end{array}$ \\
\hline Overlay & $\begin{array}{l}\text { Functional } \\
\text { symptoms }\end{array}$ & $\begin{array}{l}\text { Possible functional } \\
\text { stroke }\end{array}$ & $\begin{array}{l}\text { Stroke with } \\
\text { functional sx }\end{array}$ & $\begin{array}{l}\text { Right thalamic/ post limb } \\
\text { internal capsule infarct } \\
\text { with functional overlay }\end{array}$ \\
\hline Functional & Stroke & $\begin{array}{l}\text { Small left hemisphere } \\
\text { infarct }\end{array}$ & $\begin{array}{l}\text { Anxiety } \\
\text { exacerbated } \\
\text { physical } \\
\text { pathology } \\
\end{array}$ & $\begin{array}{l}\text { Decompensation related } \\
\text { to anxiety }\end{array}$ \\
\hline Overlay & TIA & $\begin{array}{l}\text { Recurrent TIA/Capsular } \\
\text { warning syndrome }\end{array}$ & TIA & ?TIA \\
\hline Functional & $\begin{array}{l}\text { Stroke or } \\
\text { functional }\end{array}$ & $\begin{array}{l}\text { ?Decompensation } \\
\text { ?functional overlay }\end{array}$ & $\begin{array}{l}\text { Stress } \\
\text { exacerbated } \\
\text { physical } \\
\text { pathology } \\
\end{array}$ & $\begin{array}{l}\text { Exacerbation of lacunar } \\
\text { stroke symptoms in } \\
\text { context of probable } \\
\text { stress }\end{array}$ \\
\hline Functional & Possible stroke & $\begin{array}{l}\text { ?Dissection } \\
\text { ?Demyelination }\end{array}$ & $\begin{array}{l}\text { Stress } \\
\text { exacerbated } \\
\text { physical } \\
\text { pathology } \\
\end{array}$ & $\begin{array}{l}\text { Migraine flare up by } \\
\text { stress symptoms }\end{array}$ \\
\hline Functional & Stroke & $\begin{array}{l}\text { Right lacunar } \\
\text { syndrome }\end{array}$ & $\begin{array}{l}\text { Transient } \\
\text { neurological sx }\end{array}$ & $\begin{array}{l}\text { Transient neurological } \\
\text { symptoms }\end{array}$ \\
\hline Functional & Stroke & $\begin{array}{l}\text { Stroke (suspected } \\
\text { stroke) }\end{array}$ & $\begin{array}{l}\text { Other stroke } \\
\text { mimic dx with } \\
\text { functional sx }\end{array}$ & $\begin{array}{l}\text { Bell's Palsy and } \\
\text { Functional Left } \\
\text { Hemiparesis }\end{array}$ \\
\hline
\end{tabular}


Appendix B. Questionnaire subscale totals at follow-up for participants identified with only functional symptoms versus functional 'overlay'.

\begin{tabular}{|c|c|c|c|c|c|}
\hline \multirow[b]{2}{*}{ Questionnaire } & \multirow[b]{2}{*}{ Sub-scale (each score out of 100) } & \multicolumn{2}{|c|}{$\begin{array}{l}\text { Functional } \\
\text { only }(n=24)\end{array}$} & \multicolumn{2}{|c|}{$\begin{array}{l}\text { Functional } \\
\text { 'Overlay' }(n=7)\end{array}$} \\
\hline & & Mean & SD & Mean & SD \\
\hline \multirow{8}{*}{$\begin{array}{l}\text { Short-form Health } \\
\text { Survey }\end{array}$} & Physical functioning & 58.13 & 32.36 & 60.0 & 15.55 \\
\hline & $\begin{array}{l}\text { Role limitations due to physical } \\
\text { health }\end{array}$ & 36.46 & 43.60 & 21.43 & 42.86 \\
\hline & $\begin{array}{l}\text { Role limitations due to emotional } \\
\text { problems }\end{array}$ & 55.56 & 43.59 & 26.73 & 46.00 \\
\hline & Energy/fatigue & 38.96 & 26.95 & 24.29 & 13.05 \\
\hline & Emotional well-being & 51.83 & 32.68 & 64.57 & 25.45 \\
\hline & Social functioning & 45.31 & 35.51 & 50.0 & 34.61 \\
\hline & Pain & 45.73 & 37.49 & 47.86 & 25.14 \\
\hline & General health & 39.79 & 22.43 & 46.68 & 25.23 \\
\hline \multirow{2}{*}{$\begin{array}{l}\text { Hospital Anxiety } \\
\text { and Depression } \\
\text { Scale }\end{array}$} & HADS Anxiety total & 9.54 & 6.65 & 8.29 & 6.78 \\
\hline & HADS Depression total & 7.25 & 5.38 & 5.57 & 4.72 \\
\hline \multirow{6}{*}{$\begin{array}{c}\text { Cognitive } \\
\text { Behavioural } \\
\text { Responses } \\
\text { Questionnaire }\end{array}$} & Fear avoidance total & 5.75 & 2.82 & 5.0 & 3.46 \\
\hline & Damage beliefs total & 6.71 & 2.35 & 6.29 & 2.87 \\
\hline & Embarrassment avoidance total & 5.29 & 4.81 & 2.0 & 3.70 \\
\hline & Symptom focusing total & 7.33 & 3.61 & 7.57 & 4.12 \\
\hline & All or nothing behaviour total & 7.58 & 4.20 & 7.14 & 3.39 \\
\hline & Resting behaviour total & 5.29 & 3.51 & 4.86 & 3.76 \\
\hline \multirow{6}{*}{$\begin{array}{l}\text { Work and Social } \\
\text { Adjustment Scale }\end{array}$} & Work impaired & 5.33 & 3.13 & 3.33 & 3.72 \\
\hline & Home management impaired & 4.50 & 2.89 & 4.17 & 2.56 \\
\hline & Social leisure impaired total & 4.32 & 3.08 & 3.14 & 3.08 \\
\hline & Private leisure impaired total & 2.83 & 2.90 & 3.86 & 2.61 \\
\hline & Relationships impaired total & 2.92 & 3.27 & 2.83 & 3.49 \\
\hline & WSAS total & 19.79 & 12.94 & 15.86 & 10.24 \\
\hline \multirow{8}{*}{$\begin{array}{c}\text { Brief Illness } \\
\text { Perception } \\
\text { Questionnaire }\end{array}$} & Consequences & 6.25 & 2.89 & 5.86 & 4.26 \\
\hline & Timeline & 5.39 & 3.03 & 4.67 & .52 \\
\hline & Personal control & 6.92 & 3.32 & 6.14 & 2.73 \\
\hline & Treatment control & 4.22 & 3.52 & 5.14 & 4.34 \\
\hline & Identity & 6.63 & 2.67 & 5.86 & 2.41 \\
\hline & Concern & 6.13 & 3.50 & 7.43 & 3.26 \\
\hline & Understanding & 5.83 & 3.34 & 4.0 & 4.29 \\
\hline & Emotional response & 6.38 & 3.33 & 7.0 & 3.56 \\
\hline
\end{tabular}


Appendix C. Presenting symptoms of participants with isolated functional symptoms and functional 'overlay'.

\begin{tabular}{|c|c|c|c|c|}
\hline \multirow[b]{2}{*}{ Symptom } & \multicolumn{2}{|c|}{$\begin{array}{l}\text { Isolated functional symptoms } \\
\qquad(\mathrm{n}=40)\end{array}$} & \multicolumn{2}{|c|}{$\begin{array}{l}\text { Functional 'overlay' } \\
\qquad(n=16)\end{array}$} \\
\hline & $\mathrm{N}$ & $\%$ & $\mathrm{~N}$ & $\%$ \\
\hline \multicolumn{5}{|l|}{ Laterality } \\
\hline Unilateral & 36 & 90 & 14 & 87.5 \\
\hline Bilateral & 4 & 4.5 & 2 & 2.3 \\
\hline \multicolumn{5}{|l|}{ Pain } \\
\hline Headache/migraine & 14 & 35 & 9 & 56.3 \\
\hline Pain in limbs or body & 11 & 12.2 & 2 & 2.29 \\
\hline \multicolumn{5}{|l|}{ Systemic / autonomic } \\
\hline Dizziness & 5 & 12.5 & 4 & 25 \\
\hline $\mathrm{LOC}^{\dagger}$ syncope & 4 & 10 & 1 & 1.1 \\
\hline Feeling slow/tired & 4 & 10 & 1 & 43.8 \\
\hline Panic & 3 & 7.5 & 1 & 6.25 \\
\hline Nausea & 3 & 7.5 & 0 & - \\
\hline Vomiting & 2 & 5 & 0 & - \\
\hline Seizure & 1 & 2.5 & 0 & - \\
\hline \multicolumn{5}{|l|}{ Speech/ swallow } \\
\hline Dysarthria/ Slurred speech & 14 & 35 & 3 & 18.8 \\
\hline Aphasia & 6 & 15 & 4 & 25 \\
\hline Stuttering & 5 & 12.5 & 0 & - \\
\hline Swallow symptoms & 2 & 5 & 0 & - \\
\hline \multicolumn{5}{|l|}{ Motor } \\
\hline Lower limb weakness & 34 & 85 & 11 & 68.8 \\
\hline Upper limb weakness & 27 & 67.5 & 14 & 87.5 \\
\hline Facial droop/ weakness & 10 & 25 & 3 & 18.8 \\
\hline Limb ataxia & 5 & 12.5 & 2 & 12.5 \\
\hline Tremor/ shaking & 5 & 12.5 & 1 & 6.25 \\
\hline Hand weakness & 3 & 7.5 & 0 & - \\
\hline Gait & 4 & 10 & 0 & - \\
\hline Onset & & & & \\
\hline
\end{tabular}




\begin{tabular}{lrrrr}
\hline Confusion/ disorientation & 5 & 12.5 & 1 & 6.3 \\
Onset on waking & 5 & 12.5 & 0 & - \\
Noticed by someone else & 2 & 5 & 1 & 8 \\
Dissociation & 1 & 2.5 & 0 & - \\
Sensory & & & & \\
Upper limb sensory change & 15 & 37.5 & 7 & 43.8 \\
Lower limb sensory change & 15 & 37.5 & 4 & 25 \\
Facial numbness & 8 & 20 & 4 & 25 \\
Visual & & & & \\
Visual loss & 9 & 22.5 & 6 & 37.5 \\
Diplopia & 2 & 5 & 0 & - \\
Nystagmus & 1 & 2.5 & 0 & - \\
Ptosis & 1 & 2.5 & 0 & - \\
Other & & & & \\
Inconsistent/ intermittent & 7 & 17.5 & 4 & 25 \\
Photophobia & 1 & 2.5 & 0 & - \\
Twitching & 1 & 2.5 & 0 & - \\
Phonophobia & 1 & 2.5 & 0 & - \\
Vertigo & 1 & 2.5 & 0 & - \\
Erratic behaviour & 0 & - & 1 & 6.3 \\
Shortness of breath & 0 & - & 1 & 6.3 \\
\hline
\end{tabular}


Appendix D. Participants report of treatment and investigations offered at 2-month follow-up.

\begin{tabular}{|c|c|c|c|c|c|c|c|c|c|}
\hline \multirow[t]{2}{*}{ Diagnosis } & $\begin{array}{l}\text { Ongoing } \\
\text { symptoms }\end{array}$ & \multicolumn{8}{|c|}{ Treatments offered } \\
\hline & & $\begin{array}{l}\text { Tailored } \\
\text { functional } \\
\text { symptom } \\
\text { treatment }\end{array}$ & $\begin{array}{l}\text { Physiotherapy/ } \\
\text { rehabilitation } \\
\text { from stroke } \\
\text { ward }\end{array}$ & $\begin{array}{l}\text { Speech } \\
\text { therapy }\end{array}$ & $\begin{array}{l}\text { Referred } \\
\text { to } \\
\text { mental } \\
\text { health } \\
\text { service }\end{array}$ & $\begin{array}{l}\text { Unspecified } \\
\text { medication } \\
\text { change }\end{array}$ & $\begin{array}{l}\text { Other organic } \\
\text { investigation }\end{array}$ & TMS & $\begin{array}{c}\text { No } \\
\text { treatment } \\
\text { offered }\end{array}$ \\
\hline $\begin{array}{l}\text { Functional symptoms only } \\
(n=25)\end{array}$ & 20 & 2 & 5 & 2 & 2 & 6 & 4 & 1 & 12 \\
\hline $\begin{array}{l}\text { Functional symptoms } \\
\text { overlaying a stroke }(n=6)\end{array}$ & 5 & 0 & 2 & 0 & 1 & 0 & 3 & 0 & 1 \\
\hline $\begin{array}{l}\text { Functional symptoms } \\
\text { overlaying other } \\
\text { condition }(n=3)\end{array}$ & 3 & 1 & 1 & 0 & 0 & 0 & 1 & 0 & 1 \\
\hline
\end{tabular}


